\title{
Gender Inequality in Chinese News Discourse: A Critical Discourse Perspective
}

\author{
Liwei Zhang $^{1}$ \& Muhammad Babar Jamil ${ }^{2}$ \\ ${ }^{1}$ Interdisciplinary Graduate Studies, University of Saskatchewan, Canada \\ ${ }^{2}$ English Department, University of Sargodha, Pakistan \\ Correspondence: Liwei Zhang, Interdisciplinary Graduate Studies, University of Saskatchewan, 310-107 \\ Cumberland Ave. S, Saskatoon SK S7N 2R6, Canada. Tel: 1-306-261-0195. E-mail: liz221@mail.usask.ca
}

\author{
Received: January 14, 2015 Accepted: February 12, 2015 Online Published: March 29, 2015 \\ doi:10.5539/ijel.v5n2p36 \\ URL: http://dx.doi.org/10.5539/ijel.v5n2p36
}

\begin{abstract}
This article explores, from the perspective of critical discourse analysis, how the news coverage of male and female Chinese Olympians of the $30^{\text {th }}$ London Summer Olympics in Chinese newspapers consistently perpetuates an ideology of gender inequality in the language through which achievement is recognized. The analysis reveals that while male athletes are described in terms which identify athletic achievement with masculinity, descriptions of female Olympians equate their achievements with submission to traditional female domestic roles. Due to the practice of the traditional kinship systems that define gender relations, newspapers in modern China constantly depict women as less competent than men, which has hindered the achievement of gender equality in Chinese society.
\end{abstract}

Keywords: critical discourse analysis, feminism, gender inequality, ideology, Confucianism

\section{Introduction}

In the $30^{\text {th }}$ London Summer Olympic Games, Chinese Olympians have made remarkable achievements. However, a comparison of the representation of female (Note 1) and male Olympians in Chinese newspaper discourse reveals a strong ideology of gender inequality the newspapers practice in portraying the former. Despite the newspapers' complimentary attitude toward both male and female Olympians' outstanding performance, the language of the reportage, ultimately constrains or even negates a discourse of superior athletic achievement by women through an emphasis on the portrayal of their traditional gender roles as well as feminine traits. By contrast, the depiction of male Olympians communicates a strong affirmation of their sports capacity and accomplishment by highlighting on their masculine features. Olympics are for breaking physical boundaries as expressed in the Olympic motto 'Swifter, higher, stronger'. Nevertheless, the unequal portrayal of female Olympians in Chinese newspaper discourse constrains, rather than transcends, the boundaries.

As Evans (1997, p. 10) argues, "a fundamentally biological construction of male and female sexuality continues to inform current approaches" to the exploration of gender inequality. Despite women and men are biologically different regarding to their reproductive anatomies, brain structures, and musculature, it does not add up to the automatic domination of men (Kimmel, 2011, p. 2). Moreover, in Chinese society, gender relation is defined not on the basis of a biological view but has its unique social cultural roots. Without accounting for the social cultural traditions that shape the portrayal of women, it is inadequate to promote a change in the unequal representation of female Olympians in Chinese newspaper discourse, let alone that in the problem of gender inequality. As Lazar (2005, p. 13) states, "[i]nvestigations of the interrelations between gender, power, ideology and discourse are necessarily complex and multifaceted, which explains why feminist studies and CDA alike (and feminist CDA at their confluence) are open to interdisciplinary research". In this article, grounding on an elaboration on Chinese feminism and the social cultural traditions that define gender relations in traditional Chinese society, I aim to explore how the traditional hierarchal gender order is being perpetuated and publicized "with reference to distinct themes, outlining women's responsibilities and attributes in sexually implicated contexts and relationships" (Evans, 1997, p. 4).

To this end, I will draw upon the news coverage of male and female Chinese Olympians during the $30^{\text {th }}$ London Summer Olympic Games held in London (27 July 2012 to 12 August 2012, London Time, Britain; and 27 July 
2012 to 13 August 2012, Beijing Time, China) in three Chinese newspapers, including both that in Mandarin and English. Namely, the central governmental electronic Mandarin-only newspaper China Sports Daily, and the provincial newspaper Heilongjang Daily (published in Heilongjiang province in northeast China), as well as the central governmental English newspaper Xinhuanet.

As Markula (2009, p. 2) argues, it is "pertinent to analyse how newspaper coverage depicts Olympic athletes in their local, national context, but also provide comparison points regarding the commonalities between the news media in different [languages]" as it "provide[s] a 'global' reading of the differences and similarities between [...] [the] coverage of the Olympics and their representation of women athletes [through different languages in the same local context]". Thus, an analysis of both Mandarin and English news texts that represent female Olympians in China would demonstrate how the gender ideology not only impacts the objective interpretation of gender relations on readers in China but also that on speakers of English in either SARs (Special Administrative Regions) in China or around the world when the reportage is circulated globally.

\section{Literature Review}

Researches on the issue of gender inequality in linguistic studies in China focus mainly on contrastive analysis of Mandarin and English on topics such as lexis and translation (see Chen, 2012; Pan, 2001; Xiao \& Xiao, 2003; Feng, 2003; He, 2003; Fan \& Zheng, 2007), and few are on examining texts that are purely in Mandarin (see Quan, 2004; Shi, 2007; Mo \& Jiang, 2006). In addition, while most studies apply theories of Lexics, Pragmatics, and Systemic Functional Linguistics (SFG), less attention has been paid to the exploration of gender inequality from the perspective of CDA. Among the existing studies (see Wang, 2009; Dai, 2008; Qin, 2009), only one examined the ideology of gender inequality by analyzing text that is in Mandarin (see Wang, 2009). Therefore, instead of a contrastive analysis, an exploration of English news texts complementary to that of Mandarin in this article would provide us a view of how a similar gender ideology is being perpetuated to wide scale in China.

However, despite existing CDA studies on gender inequality in China has drawn upon newspaper discourse (see Woman Journalists Association in the Capital, 1995; Yu, 2010; Tan, 2009), there is a lack of research that examines sport news. As Dong (2003, p. 177) argues, "[s]port has been virtually neglected in mainstream feminist studies, although arguably it has played a considerable part in the world". Thus, based on an exploration of Mandarin and English sports news texts, in this article, I aim to explore how the ideology of gender inequality is being widely perpetuated in Chinese newspaper discourse.

\section{Methodology}

\subsection{Method}

Critical discourse analysis (CDA), which emphasizes the role of language in shaping social relations, saw its emergence in the 1970s (Wodak \& Michael, 2001, p. 5) and has been interpreted from a variety of perspectives (see Van Dijk, 1995, 2008; Wodak \& Michael, 2001; Wodak, 2005; Fairclough, 1989, 1992, 1995, 2005). The primary objective of CDA, according to Fairclough (2005, pp. 76-77), is to account:

$[\mathrm{T}]$ he ways in which and extent to which social changes are changes in discourse ... and discourse (re)constructs social life in processes of social changes, [...] [and also to] identify through analysis the particular linguistic, semiotic and 'interdiscursive' features of 'texts' (in a broad sense) which are a part of processes of social change, but in ways which facilitate the productive integration of textual analysis into multi-disciplinary research on change. (emphasis added)

In other words, CDA commits itself to a change in the asymmetrical social power relationship through a change in the ideological use of language in discourse. As Habermas (1977, p. 259) puts it, "language is also a medium of domination and social force. It serves to legitimize relations of organized power". By examining the news representation of male and female Olympians, we aim to reveal how news language in the Chinese newspapers empowers male Olympians while disempowers female.

According to Fairclough (1989, pp. 25-26), discourse constitutes three dimensions which he labelled as texts, interactions (process of production, process of interpretation), and contexts (social conditions of production, social conditions of interpretation) (emphasis in original). Corresponding to the three dimensions of discourse, Fairclough (1989, p. 26) distinguishes three phases of conducting CDA, namely, description, interpretation, and explanation of the text (emphasis added). In the phase of description, an analyst identifies and labels "the formal features (formal properties) of a text" (Fairclough, 1989, p. 26). In this context, it is to identify the dominant ideological language the newspapers employ in describing the Olympians. In the phase of interpretation, a critical discourse analyst "is concerned with the relationship between text and interaction-with seeing the text as the product of a process of production, and as a resource in the process of interpretation" (Fairclough, 1989, p. 26). In 
other words, in interpretation, critical discourse analysts are concerned with how texts are produced as a process of meaning construction. Therefore, by analysing the semantic meanings different language units, such as vocabulary and clause communicate, we are able to identify how the ideology of gender inequality in the Chinese newspapers is being produced. Lastly, in the stage of explanation, a critical discourse analyst "is concerned with stating the relationship between interaction and social context - with the social determination of the processes of production and interpretation, and their social effects" (Fairclough, 1989, p. 26). Put another way, in the stage of explanation, a critical discourse analyst accounts for the influence of social contexts in shaping a particular type of ideology. Grounding on the description and interpretation of the news texts, we will finally explain how the social cultural roots of gender relations in traditional Chinese society affect the representation of women in modern Chinese society.

\subsection{Research Questions}

In this article, I aim to answer the following three research questions:

a. What dominant textual language do China Sports Daily, Xinhuanet, and Heilongjiang Daily employ in representing male and female Chinese Olympians?

b. What gender ideologies emerge in the depiction of the Olympians in the news texts?

c. What are the contexts for the perpetuation of the gender ideologies against female Olympians in Chinese newspaper discourse?

\subsection{Data Selection}

As is forecasted earlier, in this article, we will conduct a critical discourse analysis of news texts in three Chinese newspapers. Namely, the electronic Mandarin-only central governmental newspaper China Sports Daily and the provincial newspaper Heilongjang Daily published in Heilongjiang province in northeast China, as well as the electronic English central governmental newspaper Xinhuanet.

China Sports Daily. Launched in 1958, China Sports Daily 'is a specialized newspaper on sports and it is run by China's Physical Education and Sport Committee' (Note 2). It is:

Designed to popularize physical education and exercises and elevate the Chinese' [sic] people level in sports competition, China Sports Daily clarifies the government's guidelines, policies, laws and regulations on sports, makes readers know the status and roles of sports in China's socialist modernization, and provides them the latest news of sports competitions at home or abroad (Note 3). (emphasis added)

As for the volume of China Sports Daily, it changes according to the quantity of news to be published each day. Basically, there are four to twelve volumes (Note 4) in China Sports Daily, including Competition News, Comprehensive News, National Fitness, Football Observation, Boutique Preview, School Physical Education, Sports Lottery World, Competition · News, Olympics · Arena, Olympics $\cdot$ Synthesis, Olympics $\cdot$ Special Topics, and Olympics $\cdot$ Voice. In this article, I will select news samples from the last five sections (see bold) that portray male and female Chinese Olympians in the $30^{\text {th }}$ London Olympic Games.

Heilongjiang Daily. Established in 1945, Heilongjiang Daily is a newspaper published in one of the northeast provinces in China-Heilongjiang (Note 5). It is not only a governmental newspaper but also one of the earliest authoritative provincial governmental newspapers founded in China that disseminates in first time news on different aspects of social life (Note 6). The volume of Heilongjiang Daily changes from four to twelve according to the change of topics. In addition, the newspaper include sections of Important News, Special Issues, Current News, Focus on Current Affairs, Olympic Games, Harbin News, Today's Click, Public Announcements, Comprehensive Reports, Tourism, World, Photography and Drawing, and Special Issues on Theories. In this article, I will select news samples from the section of Olympic Games (see bold) that depict male and female Chinese Olympians in the $30^{\text {th }}$ London Olympic Games.

Xinhuanet. As an online news provider of the Xinhua News Agency, another central governmental newspaper Xinhuanet was launched in 1997 and was officially named Xinhuanet on 10 March 2000 (Note 7). It is "an important information organ of the central government, and an important platform for building up China's online international communication capacity" (Note 8), which aims to provide "around-the-clock news release with leading online public opinion at home and setting a good image of China abroad as its main task" (Note 9). In addition, it is 'most often the first to report China's major breaking news events, laws and regulations, appointments and removals of high-ranking officials' (Note 10).

The volume of Xinhuanet includes four major categories (Note 11). Respectively, Global Edition, which includes China, World, Business, Culture \& Edu, Sports, Entertainment, Sci \& Tech, Health, Travel, In-Depth, and Odd 
News; Services, which includes Markets, Weather, World Clock, Maps, Lifestyle, Art, Movie, Music, Fashion, and Theater; Live in China, which includes Travel, Business, Education, Jobs, Immigration, Marriage, Adoption, Residence, Study Zone, Books, Useful Info, and Food; and Database, which includes About China and Topics. In this article, I will select news samples from the section of Sports in the Global Edition (see bold) that represent male and female Chinese Olympians in the $30^{\text {th }}$ London Olympic Games.

\section{Analysis and Findings}

\subsection{Highlighting the Masculinity of Male Olympians}

In portraying male Olympians, the three newspapers consistently compliment on the Olympians' achievements by highlighting their strength, power, and dominance. To demonstrate, we may examine the following examples:

China Sports Daily

E.g.1: 这一天，孙杨挥臂怒吼、兴奋落泪、畅快一笑，让我们看到了一个属于 21 岁大男孩的率性与纯真。 (Note 12)

(On this day, Sun Yang was roaring while waving arms, shedding tears with excitement, and smiling with freeness, showing us the frankness and innocence that belong to a 21-year-old boy.)

E.g.2: 夺冠后的孙杨一跃坐在了泳绳上, 他张开双臂向全世界展示自己的力量, 用手势向世界宣告自己 是王者, 挥拳砸水发泄自己长久压抑的情绪。(Note 13)

(After winning, Sun Yang sat on the swimming ropes with a leap. He opened his arms showing the world his strength, and announced to the world that he is a king by a hand gesture, as well as vented his long-repressed emotions by smashing the water with fists.)

\section{Heilongjiang Daily}

E.g.1: 最后 50 米，孙杨的冲刺强劲而有力，他逐渐把朴泰桓甩开一个身位，最终孙杨以 3 分 40 秒 14 率 先撞线...(Note 14)

(In the last 50 meters, Sun Yang's sprint was strong and powerful. He gradually made Pu Taihuang lag behind for one person's distance and finally hit the finishing line in 3 minutes 40 seconds and 14 microseconds.)

E.g.2: 当孙杨到达终点时, 游泳馆沸腾了, 之间孙杨紧握双拳。(Note 15)

(When Sun Yang reached the destination, the aquatic center was boiling, during which time Sun Yang clenched his fists tightly.)

\section{Xinhuanet}

E.g.1: He punched the water in delight and let out an extended bellow. (Note 16)

E.g.2: Lin displayed his explosiveness in the decider, lashing smashes to pull ahead. (Note 17)

In China Sports Daily, the verbs roaring (怒吼; nuhou), showing (展示; zhanshi), announced (宣告; xuangao), as well as smashing (砸; za), and the nouns strength (力量; liliang), king (王者; wangzhe), fists (拳; quan) demonstrate us a fierce, dominant, and supreme figure of the male Olympian. Similarly, in Heilongjiang Daily, the adjectives strong (强劲; qiangjin), powerful (有力; youli), and the phrase clenched his fists present us an unconquerable and aggressive image of male Olympians. Lastly, in Xinhuanet, a deployment of the nouns bellow, explosiveness, and the phrases punched the water, lashing smashes construct male Olympians as fierce, ambitious, and valorous masculine beings.

In all, the dominant language the three newspapers employ in portraying male Olympians reveals the affirmative attitude the newspapers express toward male Olympians' achievements through an emphasis on their masculine features. However, the presentation of female Olympians in the three newspapers is characterized by an undermining attitude towards their sports competence through a highlight on their feminine traits. In the sections to follow, we will then examine how the ideology of gender inequality is being perpetuated through the language of different semantic themes.

\subsection{Denying the Great Athletic Potential and Outstanding Performance of Female Olympians}

In depicting female Olympians, the three newspapers communicate a strong denial of the Olympians' great athletic potential and outstanding performance by constantly comparing and evaluating their performance against male's as if male Olympians are standards. As a case in point, we may consider the following examples: 


\section{China Sports Daily}

E.g.1: 而令人惊叹的最后 50 米，小叶只花了 28 秒 93 ，比赢得 400 米个人混合泳金牌的罗切特用时还 少了 0.17 秒。(Note 18)

(However, in the stunning final 50 meters, Little Ye only used 28.93 seconds, which is even less than the gold medalist Rochette's for 0.17 seconds in the 400 meters individual medley.)

E.g.2: 我们不妨视叶诗文为“水中博尔特”。(Note 19)

(We may consider Ye Shiwen as "Bolt in theWater". (Note 20))

Heilongjiang Daily

E.g.1: “常常和比自己更强的男孩子比试”。(Note 21)

(“And [she] often competes with boys who are much more competent than [her].")

E.g.2: 被视为中国夺得游泳金牌的有力候选人之一焦刘洋，曾在训练中游出 2 分 01 秒，其教练刘海涛称 此成绩是他“从未见过的”。(Note 22)

(Jiao Liuyang, considered as one of potential candidates for winning gold medal for China in swimming, once used 2 minutes and 1 second in training, which her coach Liu Haitao says he "had never seen before".)

\section{Xinhuanet}

E.g.1: However, her performances have raised eyebrows, with commentators questioning how she could produce such a dramatically improved performance and also swim the last 50 meters in the 400 meters medley faster than men's 400 meter champion Ryan Lochte. (Note 23)

E.g.2: Ye said that she was no match with Lochte. "How can I be compared with Lochte," she said. "His 400m result was more than 20 seconds faster than mine, and he was totally relaxed over the last part of the race. But I was trying my best to come back from behind." (Note 24)

In Example 1 in China Sports Daily, the clause which is even less than the gold medalist Rochette's for 0.17 seconds in the 400 meters individual medley communicates an assumption that it is always man who are faster than woman in the 400 individual medley, and it is a big surprise if any woman performed better. In Example 2, the reference to the male sprinter champion Bolt (博尔特; Boerte) in justifying Ye's outstanding performance reveals the ideology that the significance of female Olympians' accomplishment is only recognizable when crowned with known male Olympian celebrities' names as if male's success is real success.

In Heilongjiang Daily, the examples communicate an ideology that woman is born to be incompatible to male in sports competence. To demonstrate, in Example 1, the clause who are much more competent than [her] (比自己 更强的男孩子; bi ziji gengqiang de nanhaizi) coveys the newspaper's naturalized assumption that woman is incompatible to man in athletic skills, and it is in vain for women to try it out. In Example 2, the clause which her coach Liu Haitao says he 'had never seen before' (此成绩是他“从未见过的; ci chengji shi ta 'congwei jianguo de') communicates an ideology that it is out of people's expectation that woman is capable of breaking record.

In Xinhuanet, a shared ideology is that woman is under no circumstances less capable than man in sports competence and there must be something suspicious if they outperformed man. In Example 1, the verb questioning, and the phrases raised eyebrows and dramatically improved performance communicate strongly the newspaper's suspicion of the female Olympian's fast progress and her stunning performance. This ideology is illustrated most clearly when it says that she swim the last 50 meters in the 400 meters medley faster than men's 400 meter champion Ryan Lochte as if male Olympians are the criteria of assessing the extent to which female Olympians' performance is normal. In Example 2, by quoting (in)directly the female Olympian's undermining comments on her own athletic competence that Ye said that she was no match with Lochte, and 'How can I be compared with Lochte', 'His 400m result was more than 20 seconds faster than mine, he was totally relaxed over the last part of the race. But I was trying my best to come back from behind', the newspaper is aiming to legitimatize its biased representation of female Olympians.

To conclude, the depiction of female Olympians in the three newspapers communicates an ideology that sports women are born to be less competent than sports men do. Despite female Olympians have, in a variety of cases, outperformed male, there is a strong discrimination against female Olympians' sports competence because of their female sexuality, or the biological features that distinguish them from male. Due to the misinterpretation of "nei-wai" (i.e. in-out) spatial bipolar gender distinction system proposed in Confucian classics, the society believes that women are to act in nei (in) - he private domain, and men in wai (out) - the public, both of whom are not permitted to transgress the other's space (Rosenlee, 2006, p. 69). Consequently, when women enter wai-the 
public domain that belongs to men and compete with them, they are not only being discouraged but also suspected for their competence, let alone having their competence recognized.

\subsection{Emphasizing the Obedience of Female Olympians to Authorities}

In addition to a denial of woman's great athletic potential and outstanding performance, there is simultaneously an emphasis on their obedience to authorities - coach and farther, in China Sports Daily and Xinhuanet. To illustrate, we may take the following sentences as examples:

China Sports Daily

E.g.1: 这个时候，坐在场边的教练薛保全马上起身，郭文珺也“知趣”地放下枪走向了教练。薛保全拍着郭 文珺的肩膀，说了很长时间。(Note 25)

(At this time, the coach Xue Baoquan sitting on the sideline immediately got up, and Guo Wenjun also put down the gun accordingly and walked toward her coach. Xue Baoquan patted Guo Wenjun's shoulder and talked to her for a long time.)

E.g.2: “这个小姑娘从来不吵不闹，你给她多少任务，她都会完成。教练交代游 10000 米，她只会游 12000 米, 绝不会游 9900 米。” (Note 26)

("This girl never quarrels, and no matter how many tasks you give her, she will complete them. If the coach ordered her to swim 10 thousand meters, she will swim 12 thousands meters rather than 9.9 thousand meters".)

\section{Xinhuanet}

E.g.1: In coach Wei Wei's eyes, Ye was very self-disciplined who, unlike children of her age, never skipped training sessions. (Note 27)

E.g.2: "Ordered to swim 1,000 meters, she would usually volunteer to make it 3,000," Wei said. "That's how she trained." (Note 28)

In Example 1 in China Sports Daily, the adverb accordingly (“知趣”地; zhiqudi) implicates the 'trained capacity' of sports woman in responding to the meaning of coaches' body languages. In Example 2, the phrase never quarrels and the clause no matter how many tasks you give her, she will complete them construct the female athlete as an agentless and passive recipient of the orders of coaches. Consequently, the emphasis put on describing female Olympians' obedience to coaches is in fact a conscious negation of acknowledging their great athletic competence.

Similarly, in Example 1 in Xinhuanet, the adjectival phrase very self-disciplined and the clause never skipped training sessions present us a highly obedient and conscious woman who never breaks rules in training. Moreover, in Example 2, the verbs ordered and volunteer establish an absolute authority of the male coach and the absolute obedience of the female Olympian as she is even willingly to take on more training tasks. Consequently, female Olympians' success, or at least their dedication, reflects less on their own commitment and focus than on their willingness to subordinate themselves to the male coach's authority. This submissiveness becomes a necessary element in the media's ability to "sell" their success to the public.

The virtue of obedience women are expected to display in Chinese society has its deep roots in traditional Chinese culture, and some acknowledgement of this traditional symbolic language of female virtue is (unconsciously) required to establish the ethos of female athletes. According to Andors (1983, p. 13), in traditional Chinese society, any woman whose behaviours embody 'the three obediences', referring to '[i]n youth a girl was obedient to the wishes of her father; when married, to her husband; and in widowhood, to her son', would be regarded as ideal woman. In each of the three types of obediences, men are invariably the ones to whom women are supposed to obey to. As an incarnation of the father figure, male coaches, in the news texts, are depicted as the ones to whom female Olympians are expected to obey to.

\subsection{Emphasizing the Appearance of Female Olympians}

Another perspective on portraying female Olympians is the emphasis put on delineating their appearance through a focus on their clothing and physical condition in Heilongjiang Daily and Xinhuanet. The representation communicates an ideology that the longing for having beautiful appearance for a woman should not be forgotten under any circumstances, even during intense training. To illustrate, we may examine the following instances.

\section{Heilongjiang Daily}

E.g.1: 焦刘洋一身休闲装束, 很宽松的灰色 $\mathrm{T}$ 恤, 过膝的牛仔短裤, 白色球鞋, 光泽的短发和明亮的眼 神相映。(Note 29) 
(Jiao Liuyang is casually dressed: very loose gray T-shirt, knee-length denim shorts, white sneakers. Bright eyes matched with shiny short hair.)

E.g.2: 后来, 当地的体校老师到学校选材, 这个外表柔弱的小姑娘一下子进入了视野, 从此步入射击运动 的行列。(Note 30)

(Later on, the little girl who looks weak entered the teachers' horizon when they came to select the potential candidates. From then on she stepped into the ranks of shooting.)

\section{Xinhuanet}

E.g.1: "Actually she wanted so much to wear long hair like other girls, but couldn't do so because of her training." (Note 31)

E.g.2: "And when you like weightlifting you do not think about body shape or whether it's feminine," said Zhou. (Note 32)

In Example 1 in Heilongjiang Daily, instead of portraying the female Olympian's achievement, the newspaper depicts in detail her appearance from her head to feet. For instance, the newspaper employs the adjectives loose (宽 松; kuansong) and knee-length (过膝的; guoxi de) in portraying the style of the Olympian's clothes, and white (白 色; baise), denim (牛仔; niuzai) in illustrating the color and material of her clothes. Moreover, the newspaper also deploys the nouns T-shirt ( $\mathrm{T}$ 恤; tixu), shorts (短裤; duanku), and sneakers (球鞋; qiuxie) in specifying the category of the Olympian's clothes. As for the impression the athlete leaves on people, the newspaper says that Bright eyes matched with shiny short hair (光泽的短发和明亮的眼神相映; guangze de duanfa he mingliang de yanshen xiangying). Similarly, in Example 2, rather than representing the female Olympian's outstanding performance, the newspaper then shifted to the portrayal of her weak physical condition through the phrase looks weak (外表柔弱; waibiao rouruo).

In Examples 1 and 2 in Xinhuanet, the delineation of the hairstyle and physical structure through clauses she wanted so much to wear long hair like other girls and when you like weightlifting you do not think about body shape or whether it's feminine communicates the newspaper's assumption of the ideal feminine traits female Olympians are expected to possess. It seems that the newspapers are complimenting on the female Olympians' dedication to training without giving priority to their appearance, they are simultaneously implicating that to become a complete or "perfected" high-calibre female athlete, she needs to be made physically appealing in ways that male athletes do not; she may appear masculine, however there is still the need to acknowledge the implied standard, even if they do not literally meet it.

\subsection{Recasting the Female Olympian as Caring Mother and Virtuous Wife}

A perspective that distinguishes the representation of female Olympians in Heilongjiang Daily from that in another two news outlets is the reinforcement of the traditional family roles they are expected to play. As an illustration, we may examine the following examples:

Heilongjiang Daily

E.g.1: 她生完孩子后, 我们大家明显感觉她更加成熟了, 也许是孩子让她有了更多的动力和责任感。(Note 33)

(After she gave birth, we have increasingly felt that she was more mature. Perhaps it is because child has given her more motivation and responsibility.)

\section{E.g.2: 虽然处在调整期，但结婚生子对她比赛成绩的影响其实并不大。(Note 34)}

(Despite that she is still in the adjustment period, there is not great impact of marriage and children on her race scores.)

In the two examples above, the female Olympian (Guo Wenjun, a shooter athlete) is depicted to be a caring mother and virtuous wife as shown through clauses child has given her more power and responsibility (孩子让她有了更 多的动力和责任感; haizi rang ta you le gengduo de dongle he zerengan), and there is not great impact of marriage and children on her race scores (结婚生子对她比赛成绩的影响其实并不大; jiehunshengzi duita bisaichengji de yingxiang qishi bing bu da). However, there is an ambiguity in Example 2 as it can be interpreted as either a praise or a criticism of the female Olympian. On one hand, it can be interpreted as the newspaper's praise on the Olympian's capability of playing different social roles simultaneously (being an athlete and being a mother at the same time) without having any role being imbalanced; on the other hand, it can be interpreted as the newspaper's criticism of the Olympian that she may not have paid enough attention to taking care of her family for pursuing her career. However, regardless of the ambiguous nature of this sentence, the shared ideology is that 
women's duties are to take care of family and to act in domestic domains. As Rosenlee (2006, p. 47) remarks, "in the Chinese world, a woman is a 'woman' only because she is also a daughter, a wife, and a mother. There are no distinct qualities of "woman" as such". Therefore, "the description of a "proper woman' must also be concurrent with the normative representation of familial, kinship roles assigned to woman in terms of daughter, wife, and mother" (Rosenlee, 2006, p. 47), and the completion of fulfilling all these roles would ultimately define a "proper woman".

\subsection{Depicting the Filial Piety of Female Olympians}

Distinct from the representation of female Olympians from that in the other two newspapers, in Xinhuanet, women Olympians are represented as inheritors of the virtue of filial piety to parents. To illustrate, we may take the following cases as examples:

\section{Xinhuanet}

E.g.1: "My family owns an orchard where they grow apples. I tried to go there and work for a while and help them out, but when I entered the orchard I was too big," she said. (Note 35)

E.g.2: And whenever she got time to return, Ye would "treasure" the time and sometimes spend the whole day to knit a rose for her mom. (Note 36)

In the two examples above, the portrayal of female Olympians' filial piety to parents is represented through the willingly actions they take such as helping parents out in the orchard (see Example 1), or knit a rose for mom (see Example 2). The emphasis on the virtue of filial piety of women in the news texts communicates an ideology that women are the ones who should practice such virtue. As Rosenlee (2006, p. 123) explains, in traditional Chinese society, woman's activities are confined by "the three cultural imperatives", i.e. "filiality, patrilineality, and ancestor worship". The depiction of female Olympians in Xinhuanet is a perpetuation of the cultural imperatives which hinders the recognition of their athletic potential and competence.

\subsection{Portraying Female Olympians as Materialistic and Utilitarian Beings}

The perspective that distinguishes the delineation of female Olympians in Xinhuanet from that in the two Mandarin newspapers is the portrayal of female Olympians as passionate pursuers for materialistic things. To demonstrate, we will employ the following examples:

\section{Xinhuanet}

E.g.1: "I am a pisces so I like romantic and pretty stuff. I also love shopping but I usually don't buy, because I can seldom find the suitable clothes. I just like being a company with my friends when we shop." (Note 37)

E.g.2: The Olympics champion proposed to his girlfriend with his gold medal, and she accept [sic] it. (Note 38)

The description of the Olympian's hobby of shopping, expressed through clauses I like romantic and pretty stuff and $I$ also love shopping in Example 1, and the association of the success of proposal with gold medal, demonstrated through the clause proposed to his girlfriend with his gold medal, and she accept it in Example 2, communicate an ideology that women are superficial, materialistic, and utilitarian being who sees relationship as commodities that can be transacted.

\section{Conclusion}

This article aimed to examine how Chinese newspaper discourse communicates an ideology of gender inequality in representing male and female Chinese Olympians. Grounding on the research questions we have proposed, an analysis of the news texts reveals that while the newspapers express an affirmation of male Olympians' accomplishments through an emphasis on their masculine features, female are denied recognition for their great athletic potential and outstanding performance which is then replaced by a highlight on the traditional gender roles they are expected to perform. In this case:

[W]omen become everything men are not (or do not want to be seen to be): where men are regarded as strong, women are weak; ... where men are active, they are passive; [...] Under this rationale, which aligns them everywhere with negativity, women are denied equal access to the world of public concerns as well as of cultural representation. (Gamble, 2006: Editor's Introduction)

The perpetuation of the ideology of gender inequality in depicting female Olympians in Chinese newspapers would not only deny female athletes an equal recognition for their outstanding sports competence, but also pose a barrier to the achievement of gender equality in Chinese society. As Kimmel (2011, p. 409) argues, "gender is not a property of individuals," instead, it is "a set of relationships produced in our social interactions with one another". Therefore, rather than employing a biological view in explaining gender relations in China, an 
interdisciplinary perspective that takes into account the social cultural factors becomes essential.

\section{Acknowledgement}

The research is financed by China Scholarship Council. No. 2011662027.

\section{References}

Andors, P. (1983). The unfinished liberation of Chinese women: 1949-1980. Bloomington: Indiana University Press.

Chen, Y. (2011). The many dimensions of Chinese feminism. New York: Palgrave Macmillan. http://dx.doi.org/10.1057/9780230119185

Chen, Y. (2012). Comparative study on covert gender words in Chinese and Japanese: from a feminist perspective. Foreign Language Teaching, 1, 16-20. Retrieved from http://www.cnki.com.cn/Article/CJFDTotal-GWJX201201003.htm

Dai, H. (2008). Critical analysis of two news reports on American school gun shooting crime. Master Thesis, Nanjing Normal University, China.

Dong, J. (2003). Women, sport and society in modern China: Holding up more than half the Sky. London: Frank Cass.

Dooling, A. (2005). Women's literary feminism in twentieth century China. New York: Palgrave Macmillan. http://dx.doi.org/10.1057/9781403978271

Evans, H. (1997). Women and sexuality in China: Woman sexuality and gender since 1949. New York: Continuum.

Fairclough, N. (1989). Language and power. London and New York: Longman.

Fairclough, N. (1992). Discourse and Social Change. Cambridge: Polity Press.

Fairclough, N. (1995). Critical discourse analysis: The Critical Study of Language. London and New York: Longman.

Fairclough, N. (2001). Critical discourse analysis. In A. McHoul \& M. Rapley (Eds.), How to Analyse Talk in Institutional Settings (pp. 25-38). London: Continuum.

Fairclough, N. (2005). Critical discourse analysis. Marges Linguistiques, 9, 76-94. Retrieved from $\mathrm{http} / / / \mathrm{www}$.lancaster.ac.uk/ias/profiles/norman-fairclough

Fan, X., \& Zheng, X. (2007). Feminism and advertisement translation. Foreign Language and Literature Studies 25(3), 198-202. Retrieved from http://d.wanfangdata.com.cn/periodical_wgyywx200703010.aspx

Feng, J. (2003). A comparative study on the gender use of compliments and compliment responses in Mandarin Chinese and English. Foreign Languages Research, 2, 18-24. Retrieved from http://mall.cnki.net/magazine/Article/NWYJ200302004.htm

Freedman, E. B. (2002). No turning back: The history of feminism and the future of women. New York: Ballantine Books.

Gamble, S. (Ed.). (2006). The Routledge companion to feminism and postfeminism. London and New York: Routledge.

Habermas, J. (1977). Erkenntnis und interesse. Frankfurt: Suhrkamp.

He, X. (2003). Sexual discrimination in translation discourse. Foreign Languages and Their Teaching, 10, 40-42. Retrieved from http://lib.cnki.net/cjfd/WYWJ200310010.html

Kimmel, M. S. (2011). The gendered society (4th ed.). New York: Oxford University Press.

Lazar, M. M. (2005). Feminist critical discourse analysis: Gender, power, and ideology in discourse. New York: Palgrave Macmillan.

Markula, P. (Ed.). (2009). Olympic women and the media: International perspectives. Basingstoke: Palgrave Macmillan. http://dx.doi.org/10.1057/9780230233942

Mo, A., \& Jiang, Q. (2006). A pragmatic study of sex discriminating use of language. Foreign Language Research 4, 25-28. Retrieved from http://lib.cnki.net/cjfd/NWYJ200604005.html

Pan, J. (2001). A comparative research on sexism in both English and Chinese. Foreign Languages and Their Teaching, 3, 14-16. Retrieved from http://en.cnki.com.cn/Article_en/CJFDTOTAL-WYWJ200103004.htm 
Qin, J. (2009). Transitivity studies on feminism features in the novella Hunger. PhD Thesis, Shandong University, China. Retrieved from http://cdmd.cnki.com.cn/Article/CDMD-10422-2010067548.htm

Quan, L. (2004). Sex-based differences in the realization patterns of compliments and compliment responses in the Chinese context. Modern Foreign Languages, 27(1), 62-69. Retrieved from http://www.cnki.com.cn/Article/CJFDTotal-XDWY200401007.htm

Rosenlee, L. (2006). Confucianism and women: A philosophical interpretation. Albany: State University of New York Press.

Shi, D. (2007). A critical review of research on language and gender. Foreign Languages Research, 5, 38-42. Retrieved http://nwyj.chinajournal.net.cn/WKB2/WebPublication/paperDigest.aspx?paperID=4BA8130A-AFCE-42B 8-95A6-7FC8D1A4D7BD

Tan, N. (2009). Analysis of woman images on internet news reports - A case study of Sina social news. MA Thesis, Guangxi University, China. $\quad$ Retrieved $\mathrm{http}: / /$ www.sciinfo.cn/ShowDetail.aspx?d=1018\&id=XW000001089551\&m=

Van Dijk, T. A. (1995). Aims of critical discourse analysis. Japanese Discourse, 1, 17-27. Retrieved from http://www.discourses.org/OldArticles/Aims\%20of\%20Critical\%20Discourse\%20Analysis.pdf

Van Dijk, T. A. (2008). Discourse and power. New York: Palgrave Macmillan.

Wang, H. (2009). Language and ideology: Gender stereotypes of woman and man artists in Taiwanese tabloids. Discourse \& Society, 20(6), 747-774. http://dx.doi.org/10.1177/0957926509342379

Wharton, A. S. (2005). The sociology of gender: An introduction to theory and research. Carlton: Blackwell Publishing.

Wodak, R. (2005). Gender mainstreaming and the European Union: Interdisciplinarity, gender studies and CDA. In Michelle M. Lazar (Ed.), Feminist critical discourse analysis: Gender, power, and ideology in discourse (pp. 90-113). New York: Palgrave Macmillan.

Wodak, R., \& Michael, M. (Eds.). (2001). Methods of critical discourse analysis. London: SAGE Publications.

Woman Journalists Association in the Capital. (1995). Journalism \& Communication, 2, 35-35. Retrieved from http://lib.cnki.net/cjfd/YANJ502.007.html

Xiao, J., \& Xiao, Z. (2003). Iconicity of the markedness in English and Chinese gendered speech. Foreign Language Education, 24(3), 37-39. Retrieved from http://lib.cnki.net/cjfd/TEAC200303009.html

Yu, Y. (2010). Constructions and changes of woman images in China women's news. MA Thesis, Lanzhou University, China. Retrieved from http://lib.cnki.net/cdmd/10730-2010129609.html

\section{Notes}

Note 1. By using the vocabulary 'male' and 'female' in this article, the authors do not implicate a distinction between man and woman based on their sexuality, but merely for a consideration of the grammaticality when they are used in compounds.

Note 2. See more information on China Sports Daily at http://www.chinaculture.org/gb/en_aboutchina/2003-09/24/content_23484.htm.

Note 3. Ibid.

Note 4. See the volume of China Sports Daily at http://www.sportspress.cn/.

Note 5. See an introduction to Heilongjiand Daily at http://www.baike.com/wiki/\%E3\%80\%8A\%E9\%BB\%91\%E9\%BE\%99\%E6\%B1\%9F\%E6\%97\%A5\%E6\%8A $\% \mathrm{~A} 5 \% \mathrm{E} 3 \% 80 \% 8 \mathrm{~B}$

Note 6. See more information on Heilongjiand Daily at http://www.hljnews.cn/fou_gywm/gywm.htm.

Note 7. See more information on Xinhuanet at http://news.xinhuanet.com/english2010/special/2011-11/28/c_131274495.htm.

Note 8. Ibid.

Note 9. Ibid.

Note 10. Ibid. 
Note 11. See the volume of Xinhuanet at http://www.xinhuanet.com/english/.

Note 12. See this quotation in Section 1 in China Sports Daily published on 30 July 2012.

Note 13. Ibid.

Note 14. See this quotation in Section 8 in Heilongjiang Daily published on 30 July 2012.

Note 15. Ibid.

Note 16. See this quotation at http://news.xinhuanet.com/english/china/2012-08/05/c_123529677.htm in Xinhuanet published on 5 August 2012.

Note 17. See this quotation at http://news.xinhuanet.com/english/sports/2012-08/03/c_131757711.htm in Xinhuanet published on 3 August 2012.

Note 18. See this quotation in Section 5 in China Sports Daily published on 2 August 2012.

Note 19. Ibid.

Note 20. Bolt here refers to the Jamaican sprinter champion Usain Bolt.

Note 21. See this quotation in Section 8 in Heilongjiang Daily published on 3 August 2012.

Note 22. See this quotation in Section 7 in Heilongjiang Daily published on 27 July 2012.

Note 23. See this quotation at http://news.xinhuanet.com/english/sports/2012-07/31/c_131751303.htm in Xinhuanet published on 31 July 2012.

Note 24. Ibid.

Note 25. See this quotation in Section 2 in China Sports Daily published on 30 July 2012.

Note 26. See this quotation in Section 3 in China Sports Daily published on July 30, 2012.

Note 27. See this quotation at http://news.xinhuanet.com/english/sports/2012-08/01/c_131753620.htm in Xinhuanet published on 1 August 2012.

Note 28. Ibid.

Note 29. See this quotation in Section 8 in Heilongjiang Daily published on 8 August 2012.

Note 30. See this quotation in Section 4 in Heilongjiang Daily published on 29 July 2012.

Note 31. Ibid.

Note 32. See this quotation at http://news.xinhuanet.com/english/china/2012-08/06/c_131763145.htm in Xinhuanet published on 6 August 2012.

Note 33. See this quotation in Section 8 in Heilongjiang Daily published on 30 July 2012.

Note 34. Ibid.

Note 35. See this quotation at http://news.xinhuanet.com/english/china/2012-08/06/c_131763145.htm in Xinhuanet published on 6 August 2012.

Note 36. See this quotation at http://news.xinhuanet.com/english/sports/2012-08/01/c_131753620.htm in Xinhuanet published on 1 August 2012.

Note 37. Ibid.

Note 38. See this quote at http://news.xinhuanet.com/english/china/2012-08/12/c_131779283.htm in Xinhuanet published on August 12, 2012.

\section{Copyright}

Copyright for this article is retained by the author(s), with first publication rights granted to the journal.

This is an open-access article distributed under the terms and conditions of the Creative Commons Attribution license (http://creativecommons.org/licenses/by/3.0/). 